\title{
THE UNIQUENESS OF THE HUNGARIAN RURAL TOURISM SUPPLY
}

\author{
Márta Kóródi \\ Faculty of Economics and Business, University of Debrecen, Hungary \\ Lóránt Dénes Dávid \\ Faculty of Economics and Social Sciences, Szent István University \\ Faculty of Economics and Business, University of Debrecen, Hungary
}

Received: 8 May 2019. Revision received: 28 August 2019. Accepted: 30 August 2019

\begin{abstract}
In an increasingly competitive market for tourism service providers, it is possible to improve or preserve positions by providing a special, high-experience content assortment. Uniqueness should also be emphasized in order to increase the attractiveness of rural tourism in Hungary. From a professional point of view, the necessity of supplying basic service items (ubiquity) and the special elements (uniqueness) are unquestionable in national rural tourism, but their actual optimal proportion is undetermined. The aim of the research is to investigate the uniqueness of rural tourism products, to identify which ones are the general and the specific elements of supply. The questions of the exploratory research will be answered by analysing a database of registered service providers of FATOSZ (Hungarian National Association of Rural and Agrotourism) based on a set of criteria designed to measure uniqueness. Data from the primary observation were analysed using descriptive statistical methods and contextual analysis. The main findings of the research were related to the experience content, which are closely related to the accommodation, environment and tourists' activity during the stay. Consequently, those rural accommodation providers that have a low experience content offer should either develop their experience base (material conditions) or experience generation activities (e.g. animation). The research confirms that conscious development based on experience management can transform the general offerings into a special, unique offerings that are attractive to tourists.
\end{abstract}

Key Words: tourism development, tourist supply, differentiation, rural tourism, uniqueness, experience management, rural development.

JEL Classification: L83, R11, Z32

\section{Introduction}

The phrases "ubiquity" and "uniqueness" are the most common indicators used to qualify the resources of a given area in the terminology of regional economics. Especially in terms of supply the "uniqueness" expression marks the unique particularity as an alternative to generality, which can be called ubiquity in terms of availability for everyone within the given supply constraints. Such tourism-related concepts can be applied in many levels. Destination management and service providers also communicate rather the unique character, which can be taken into account as an attraction factor, but there are 
also ubiquitous elements in attractions. Ubiquity in case of tourism refers to a set of supply elements that includes the commonly and generally available services required for a tourist stay. However, the content of the general indicator - especially in tourism depends on the area and time.

The necessity of supplying basic service items (ubiquity) and the special elements (uniqueness) are unquestionable in national rural tourism in terms of professionalism, but their actual optimal proportion is not determined. Rural tourism has always been built on mouth propaganda, but how use service providers the community communication opportunities in their communication, whether they emphasize the content and quality of the general services rather than the occasional, special services, how impressive experience-centered information on platforms is. The previous questions of the exploratory research are answered in the course of analyzing the database started from the FATOSZ 's ((Hungarian National Association of Rural and Agrotourism) website based on the criteria developed by observation according to each platform, webpages.

The study examines how this features are accomplished in rural tourism, what kind of characteristics it has. As uniqueness of product is a subjective experience, it is expedient to develop a rating scale so that more realistic results can be obtained by comparing each other.

At the same time, the development works in such a way that the previously unique elements of the offer become general, and after a while the tourists does not consider it special, the services become habitual, and a kind of tourists' expectation. But the statements about general and unique supply elements can be considered valid for several years.

\section{Theoretical background}

Tourism needs are very different, characterized by certain similarity between service groups, and diversity in terms of experience contents. This may come from the fact that the previous system of concepts can be identified with physiological needs (transport, accommodation, meals), the latter satisfying needs at a higher level of hierarchy, such as social contact and the needs of self-actualization. Due to the abundant supply, the choice of services that meet the same needs (Morrison, 2018) also poses a challenge for the tourist during the travel decision or travel. Information described by the presentation of the offer will support the choice. By communicating the ubiquities and the uniqueness, the value for money perceived by tourists will be more advantageous.

The scope of the ubiquity is expanding, as the breakfast buffet has become universal in the past, nowadays a minimal wellness offer is general in a hotel. That is, the unique assortment of elements has to undergo continuous development due to the delay in reaching the status of ubiquity in the course of efficient supply management, so that the tourist can maximize the perceived and actual value and be satisfied. In addition, consumer expectations are changeable, and the creation of a unique offering means a diversified collection of distinctive services or service features. 
According to Gonda (2016), the tourism product is a complex package of services that the tourist uses during his / her trip and during the stay in the given reception area. At the same time, this set of services may be partially or completely non-pre-assembled, expandable with service features on site, and it will only be finalized after the trip (FehérKóródi, 2008). For successful product development in case of standard tourist product as well the experiences should be created (Robert - Hall, 2004) not only in rural tourism but also in several fields of tourism. For this purpose, it is required the multiplicity of reserve elements of tourist products. The adventure, excitement, fantasy mobilization such an activity fills an experience creating function, but tourist experiences are as many various as tourist avails services.

In practice, market-oriented service providers have a central role in the development of supply in the corporate strategy. The value-price relationship that forms the productspecific supply policy for services (which are not necessarily tangible) plays a significant role in promising experience as a subjective factor. In addition, the image of the service provider has a greater influence, which is also taken into account by the potential tourist before deciding if other groups of guests outside their own segment are offered additional options. The application and expansion of Morrison (2018) model on a tourist as a special consumer, shows that the components of supply offering the value for tourists include composition of facilities, quality, joined facilities (up or cross selling), price, service image and communicating the promised experience.

While hospitality in rural tourism can be taken into account as a quasi-extended product, it does not appear officially in the basic utility of the product due to the legal delimitations of the service, however it is considered by the guest as part of the concept, i.e. as part of the expected product. The expected form of the product varies from market to market, from segment to segment, from country to country, depending on economic development and on time. Additional features or amenities related to services become "an integral part of the service package" over time, and development proceeds from the basic product to the extended product (Morrison, 2018). That is, the ubiquitous nature of supply must be determined at the level of utility expected by the primary target group. The development of uniqueness takes place at the level of the potential product, i.e. the range of possible future extensions (Kajzar, 2018).

Furthermore, the competitive advantage (Levytskyy, 2015) appears on two levels in the case of rural tourism services. Regarding a travel decision, it can be interpreted as in how much better (in terms of quality ubiquitous) or how much different (uniqueness-based) way the service provider satisfies the traveller in relation to his promised experience. The other level is the competitive advantage of the tourist's image after the journey expressed by the correspondence between satisfaction, experience notion and the intensity of the real experience. Due to their subjective nature in the case of service packages, i.e. tourism products, there may be a particularly large difference between the objective value and the accepted value (experience notion) as well as the value observed during the travel.

The consumer strives to maximize value (Walters \& Lancaster, 2000, Kozicka, Kot, \& Riana, 2019), but at the same time, information is much more inadequate in the case of services. The experience notion of services is more subjective than product notion, and an opportunity to create a "wow" experience arises, if the experience can be part of a related service that is beyond the promise but not communicated in detail. The "wow" 
feeling emerges only when the extended service satisfies the latent need, but the given feature is not part of the experience notion, or it triggers an "I did not even imagine this!" reaction. However, as all tourists' needs are different, it is necessary to generate alternative experiences, that is, extending the service functions to the potential value expectations (Mura \& Kljucnikov, 2018; Slusarczyk, Smolag, \& Kot, 2016).

Eventually, the satisfaction of the tourist is positively influenced by a limited extent of service availability, which is part of the customer value as functional utility (apart from emotional utility). In other words, he / she has to feel that he / she could only have the experience if he / she participated in a rare event. Satisfying a high level of needs in both products and services has a similar effect on the perceived value. In the case of products, the re-purchase rate and in the case of services the attractiveness plays a greater role because of the emotional nature in the latter sample. The value is based on quality, which can be interpreted as compliance with specified performance, expectations and the purpose of use in case of services. The specified performance expectations of rural tourism can be identified with the rural environment in the experience concept. Previous observations also play a greater role in expectations, while compliance with the purpose of use includes more objective, technical and comfort considerations.

Since the special feature of the service offering, that its non-tangible items are difficult to specify and standardize, the problem of developing quality (Androniceanu, 2017) categories represented by the sunflower images, also appears in rural tourism. The attributes are mostly functional, omitting the emotional component of the value from the qualification. They are linked to "Physical Evidence", the fifth "P", suggesting both function and quality. Portfolio management of rural tourism service providers is endowments-dependent, but is also influenced by provider skills and abilities. In general, portfolio expansion does not depend on the sunflower classification because it mainly refers to the quality of the core product. In order to meet the needs of tourists more effectively the general indicators include communication and diversification, but the communication of the given experience can be differentiated and communicating service integration is also a widespread phenomenon, instead of competitor separation.

Positioning requires the knowledge of what characteristics of tourists are used to distinguish service providers at the travel decisions, and how potential tourists perceive a given service provider, and how satisfied are those who leave. Uniqueness means from the point of view of promotion a unique selling proposition (USP) (Morrison, 2018), which helps to discriminate. Tourists also detect quality in rural tourism by comparing perceived and expected service. Customer expectations are influenced not only by the provider's communication or promise, but also by the sunflower certification. Consumer orientation in tourism at the beginning of the 21 st century has evolved into experienceorientating, the service is even more distant from the product, the intangibility is complemented by notions, imaginations, feelings, emotions, experiences (Kovács, 2014).

Managing tourist products, due to the personality of the user and on-site consumption, also means managing availability, location atmosphere, relationship between the guest and the service provider, and the provision of joint services, as well as relationships with other guests (Morrison, 2018). According to the experience theory of Kovács (2014) the experiences of the guests of rural tourism can be identified as the intersection of the groups. Included are experiences of the new situation, and those related to new 
impressions, meeting, discovery, individual challenges, nature, pleasure and age. Zátori (2014) calls the tourism service provider an experience intermediator who influences the tourist's attention and interest. Directing attention to the event can be more dynamic, and then the intensity of living increases, so the emphasis is on the generation of direct experience.

The change of management techniques conduced to the modification of development procedures and adaptation new tools and methods. Beside the currently preferred spatialbased and multi-products destination management, in certain regions henceforward it takes part in practice the spontaneous visitor management, or tourism product management based on local endowments, which can be got ahead of attraction management in absence of endowments (Kóródi, 2014). One can attain the level of experience management through the product management completed with methods of visitor management development (Mura, 2017). The concept and content of experience management became more and more familiar for destination (Stamboulis \& Skayannis, 2003) with its four stages -performance quality of tourism, tourist's experience quality, overall satisfaction, revisit intension (Cole \& Scott, 2004) - which are analysed in context in researches. The contemplation of model of Aho (2001) is more dynamic with seven stages of experience processes (orientation, attachment, visiting, evaluation, storing, reflection, enrichment), which takes into consideration previous experiences of tourist as well. The same components were defined with constant character by Gentile et al. (2007). Both complexity and multidimensionality are features of tourism experience (Walls et al., 2011), further development depend on the proportion of experience basis and experience generators (Kóródi, 2014). The experiences play an important role in upgrade of journeys; however, it cannot be realized without the tourists' active participation, it is necessary them to seek the possibility of experiencing, they must be willing and able to immerse themselves in the experience (Zátori, 2013).

\section{Methodology}

The uniqueness and experience of the content of the service was analysed on the basis of the FATOSZ ((Hungarian National Association of Rural and Agrotourism) qualified accommodation database. As a result of the certification, the service content of different sunflower-classified operators has to be diverse, however, there may be questions as to whether the most important technical elements required by the trademark represent the difference, or whether more unique items are more common in higher categories. There are 782 accommodation service providers in the database of the professional organization (two of them are not qualified, only registered). As these businesses provide the most complex services in rural tourism and are comparable, other types of service providers have not been selected for inclusion in the rated rural accommodation database. The registered features are the accommodation's name, address, website, or the host's e-mail address, number of rooms and capacity. $87.69 \%$ of the multitude have four, $10.64 \%$ three, $1.67 \%$ have two sunflowers trademark, and 1 sunflower rating has not been awarded to service providers. Information related to cleaning was based on the availability of electronic communications, because the knowledge of the service offering was important for the qualification of uniqueness and ubiquity, either through standalone or collecting websites. If there was a Facebook page for the service provider, the information contained therein was taken into consideration as well as the deviation from the official 
communication could be examined. Total pattern was created for 746 rural accommodation service providers, of which the three categories were $87.94 \%, 10.46 \%$ and $1.61 \%$ in descending order, representing the multitude appropriately.

The information on the supply has been examined according to the surroundings of the accommodation, the lay-out of the accommodation (differentiation of premises), the equipment, the tranquillity, the stress-free relaxation, the activity, the establishment of contacts, the opportunity of the community experience, and the segment-specific or thematic differentiation.

The rating was done on a six-grade scale, 0 rating meant that the given supply element was not guaranteed, a 1 rating characterized the incomplete or slight supply element, the "average ubiquitous" value was 2 , the "quality ubiquitous" ranking was rated 3 , if the supply element could be considered somewhat unique, it deserved a value of 4 , the sensational unique offer items were the highest-ranking getting a value of 5 .

The primary observation database was first analysed by descriptive statistical methods using Microsoft Excel 2013. On the one hand, a ranking of the average uniqueness measures for each aspect was developed by quality categories, and on the other hand, the relationships between the average uniqueness values were examined. Rankings can be used to identify general and unique supply elements in Hungarian rural tourism. The correlation tests show a typical ensemble of unique items appearance.

\section{Results}

In terms of electronic communication, the difference between the multitude and the panel indicates the relationship between categories and accessibility. With higher sunflower category numbers, electronic availability increases, 10 (2 sunflowers category), 6 (3 sunflowers category), and 4 (4 sunflowers category) percent of categories are not available on the online communication platform. The received evaluations were summarized in three aspects. On the one hand, the values of the attributes could be averaged, and on the other hand, the service providers could obtain an average score from the points of attributes, and thirdly, the comments made by the evaluators facilitate the description of the experience elements.

In the case of averaging the attributes (Figure 1) the relationship between experience content and quality has been confirmed, although the difference between the categories does not represent a strikingly marked contrast. The "two sunflowers" group scored the highest average rating for the environment and surroundings, the "three sunflowers" group was distinguished due to the differentiation of premises, while the one receiving four sunflowers appeared in the offer of leisure activity (Boda, 2018). The weaknesses show the differentiation of the premises in the "two sunflowers" group, the communal character and the segment specificity in the "three sunflowers" group, and the establishment of contact in the "four sunflowers" group. 
Figure 1

Average position of supply elements in rural tourism based on ubiquity and uniqueness by classification categories

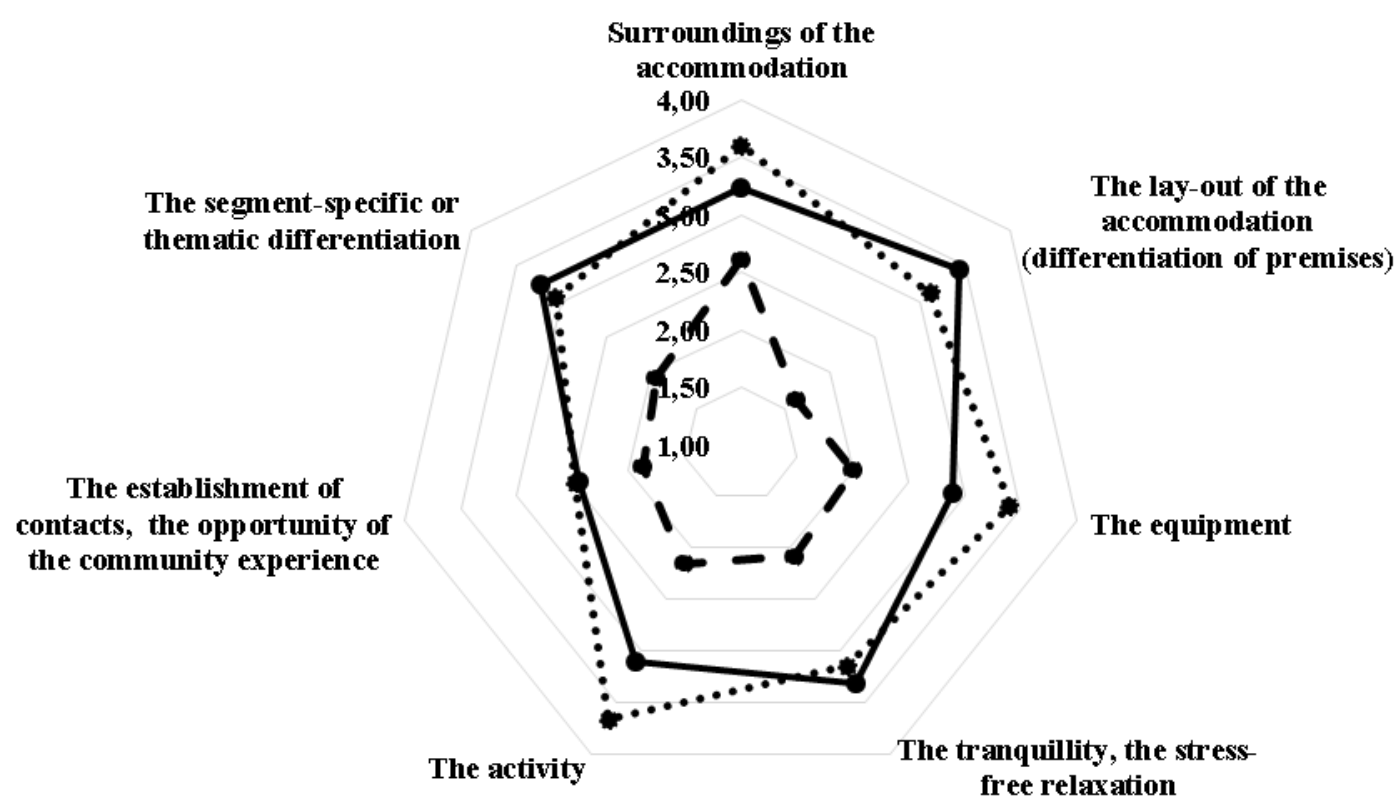

- 2 sunflowers category

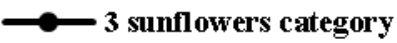

.. - 4 sunflowers category

Source: authors' own compilation

In terms of the three examined categories, the development of the host's average also increases with the level of quality (Figure 2). Higher rates of higher average scored service providers are found in multi-sunflowers categories. Based on uniqueness, the outstanding host can be found in all categories. This is presumably due to the knowledge and market sensitivity of the accommodation provider. Owners living far from the actual accommodation, especially in the higher category, entrusting the key, cleaning and care to a local resident as an assistant, besides the urban equipment and comfort of the house, cannot offer the realization of the experience notion for participants in rural tourism. The rural character does not appear for those service providers who apply such resource utilization. At the same time, there are a number of good practices ranging from horse sleigh to wooden bath tubs.

The results show the problem of the usefulness of local products, that is, the function attributed to local products in rural tourism is not sufficiently implemented. In the case of local products next type of process has taken place: in addition to the well-marketable, so called "traditionally Hungarian", mainly considered mass "local" products appeared genuine high-quality local products and handicraft products. It is also an interesting phenomenon that the hosts do not represent the name of the food in the offer, but the food raw material, which guarantees the originality better (e.g. Hungarian Grey Cattle or Mangalica). 
Figure 2

Proportion of average evaluation of service providers in rural tourism by classification categories

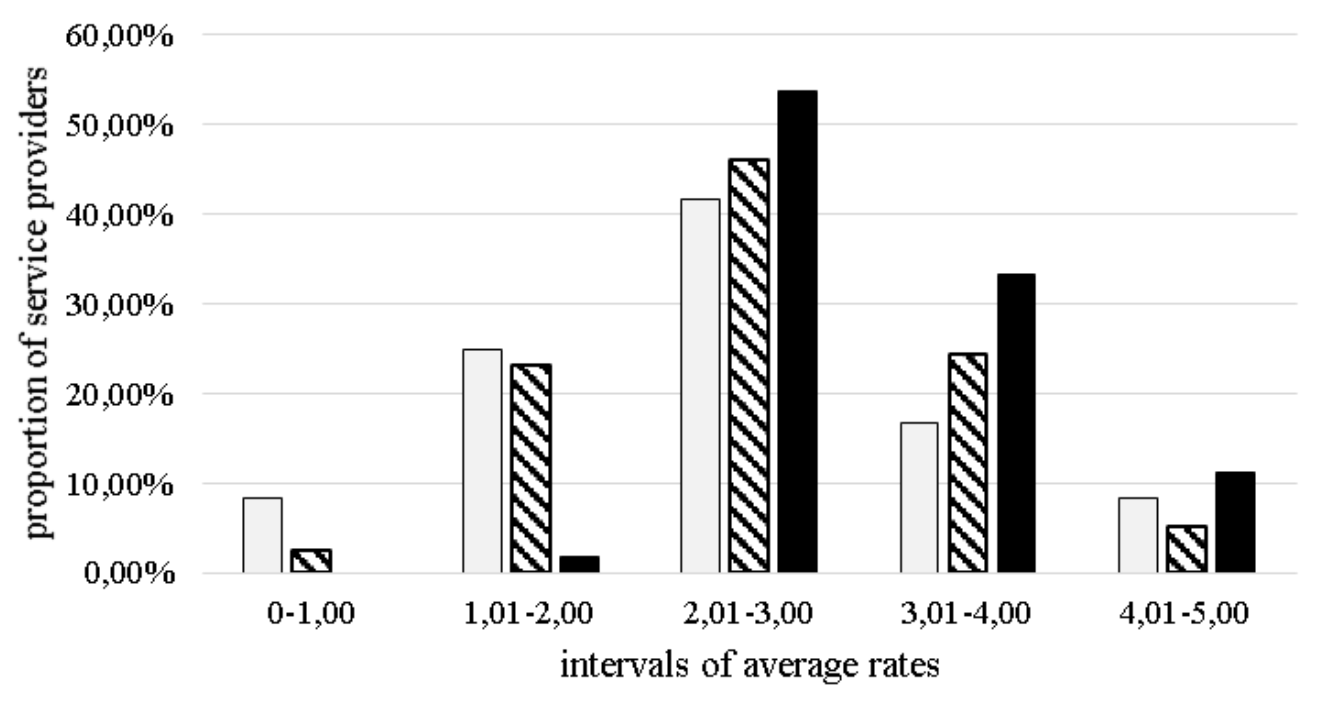

$\square 2$ sunflowers category $\quad \mathbf{Q} 3$ sunflowers category $\quad \square 4$ sunflowers category

Source: authors' own compilation

There are presumably relationships between the tested characteristics, e.g. it is likely that the accommodation providers who have higher bed capacity should provide more services, and thus they can achieve a higher average score of uniqueness. Also, the segment specificity is better enforced at these service providers. Pearson's correlation coefficients (r) characterize the direction and tightness of the relationship in pairs. Sorting results in a correlation matrix (Table 1), both assumptions can be rejected, however, it shows the existence of a stronger than average relationship between the average score of uniqueness and activity, as well as activity and surrounding of the accommodation.

Further examining the capacity, the average score of uniqueness and the average of categories, on the one hand, it can be stated that the high capacity is only an opportunity for differentiation, which is not necessarily exploited by the service providers (Figure 3). The average of the four sunflower categories appears in this quarter named "Differentiating". Smaller rural guesthouses with high score of uniqueness are considered in the group named "Little jewelry box". The three sunflower averages of uniqueness can be found here after the development, but even their services need to be enriched or differentiated to reach and exceed the average score of multitude. Those service providers, who want to earn only alternative income in addition their agribusiness, belong to the group of "Attempting" with low capacity and low degree of uniqueness. Their supply development strategy will determine their further position. Also included is the average of the two sunflowers category. Last but not least, larger capacity guesthouses, mainly providing general services, belong to the "Mass product" group, which is likely to be in demand because of the good value for money, however, a better supply-side ratio can be achieved either by further diversification or by differentiation. 
Table 1

Pairwise relations between the criteria $(\mathrm{r})$

\begin{tabular}{|c|c|c|c|c|c|c|c|c|c|}
\hline Characteristics & 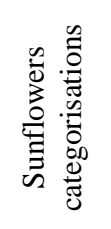 & 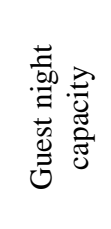 & 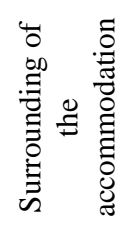 & 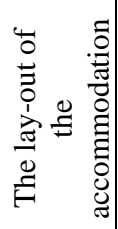 & 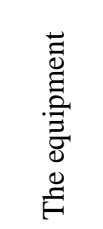 & 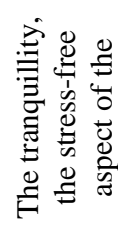 & 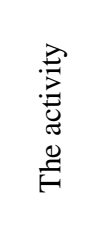 & 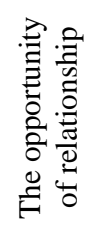 & 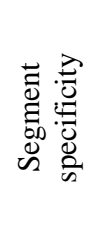 \\
\hline Guest night capacity & 0,1746 & 1 & & & & & & & \\
\hline $\begin{array}{l}\text { Surrounding of the } \\
\text { accommodation }\end{array}$ & 0,2252 & 0,0581 & 1 & & & & & & \\
\hline $\begin{array}{l}\text { The lay-out of the } \\
\text { accommodation }\end{array}$ & 0,0556 & 0,0575 & 0,3790 & 1 & & & & & \\
\hline The equipment & 0,2786 & 0,0473 & 0,2977 & 0,3469 & 1 & & & & \\
\hline $\begin{array}{l}\text { The tranquillity, the } \\
\text { stress free relaxation }\end{array}$ & 0,0582 & $-0,0214$ & 0,2794 & 0,1336 & 0,4701 & 1 & & & \\
\hline The activity & 0,3529 & 0,0557 & 0,6483 & 0,4121 & 0,3048 & 0,1825 & 1 & & \\
\hline $\begin{array}{l}\text { The opportunity of } \\
\text { relationship }\end{array}$ & 0,0800 & 0,0374 & 0,6026 & 0,3017 & 0,2638 & 0,2104 & 0,4625 & 1 & \\
\hline Segment specificity & 0,0699 & 0,0248 & 0,3015 & 0,4131 & 0,1150 & 0,1916 & 0,4627 & 0,3243 & 1 \\
\hline $\begin{array}{l}\text { Average uniqueness } \\
\text { score of rural } \\
\text { accommodation service } \\
\text { providers }\end{array}$ & 0,2496 & 0,0559 & 0,7536 & 0,6374 & 0,6339 & 0,5538 & 0,7476 & 0,6734 & 0,6019 \\
\hline
\end{tabular}

Source: authors' own compilation

Figure 3

Rural service providers' groups by their capacity and uniqueness

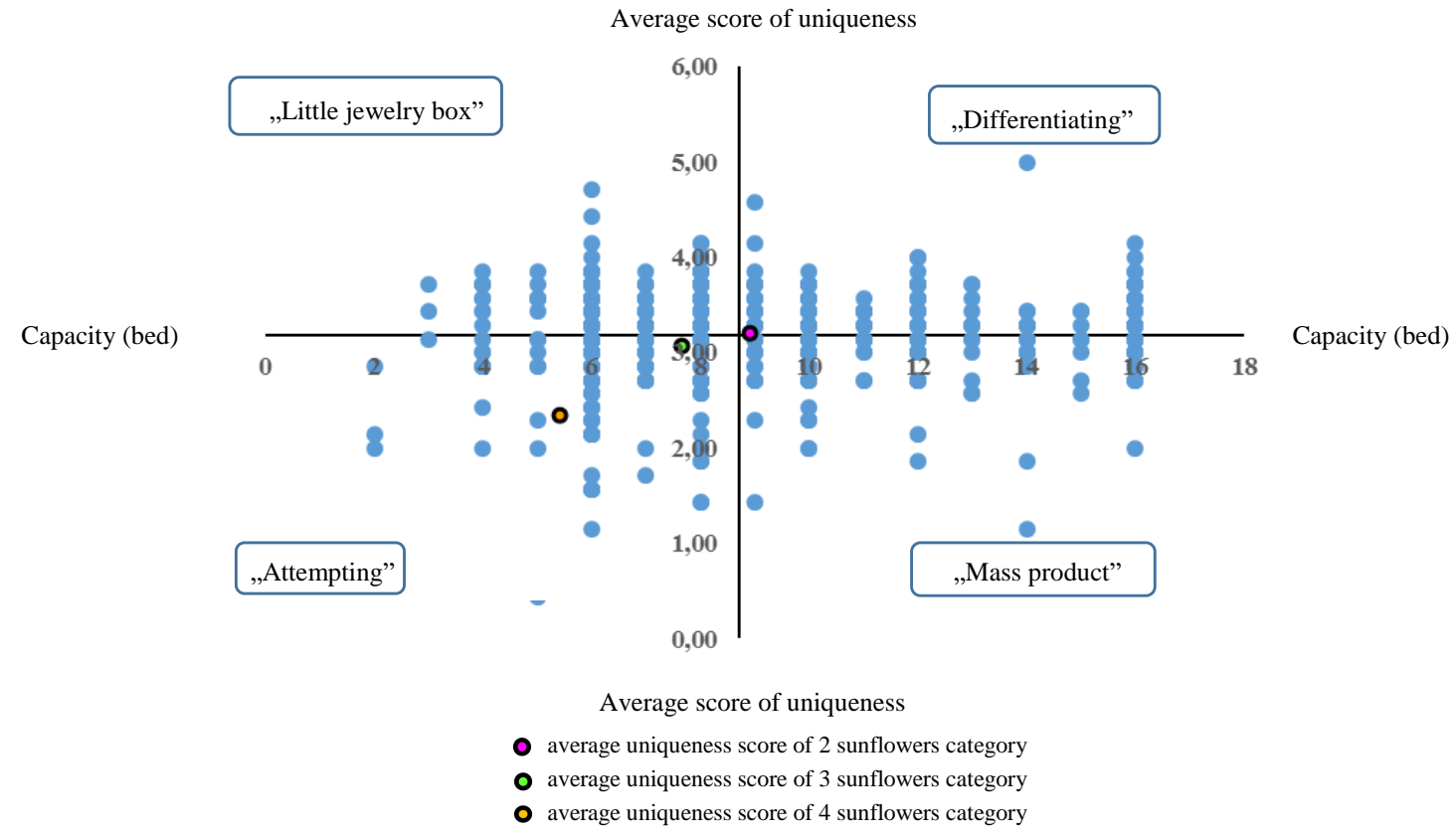

Source: authors' own compilation

Based on these facts, research questions can be answered. In rural tourism in Hungary, general product elements include calmness, good equipment, comfort, convenient and communication facilities, networking with residents. In general, they strive to meet the needs of tourists of different interests. Uniqueness and enjoyment can be captured in a 
different environment and in the leisure activities that can be performed in quality categories. This is reinforced by the context revealed between them.

The relevance of the results may be adversely affected by the fact that the research relied solely on information in electronic communications, at the same time it confirms that guests are also choosing rural tourism services based on the offer on digital platforms.

The limitations of the research are the subjectivity of the observation and evaluation method, which can be taken into account as a distorting factor. The high number of elements and the repeatability support the acceptability of the results.

\section{Discussion}

In the case of renewable, transforming rural tourism, the first issue to be addressed is the delimitation of the concept, expansion or narrowing. Two standpoints prevail. One considers rural tourism as an independent concept, and the other is the intersection of tourism in rural environments (Figure 4 and Figure 5).

Figure 4

Rural tourism as an individual definition

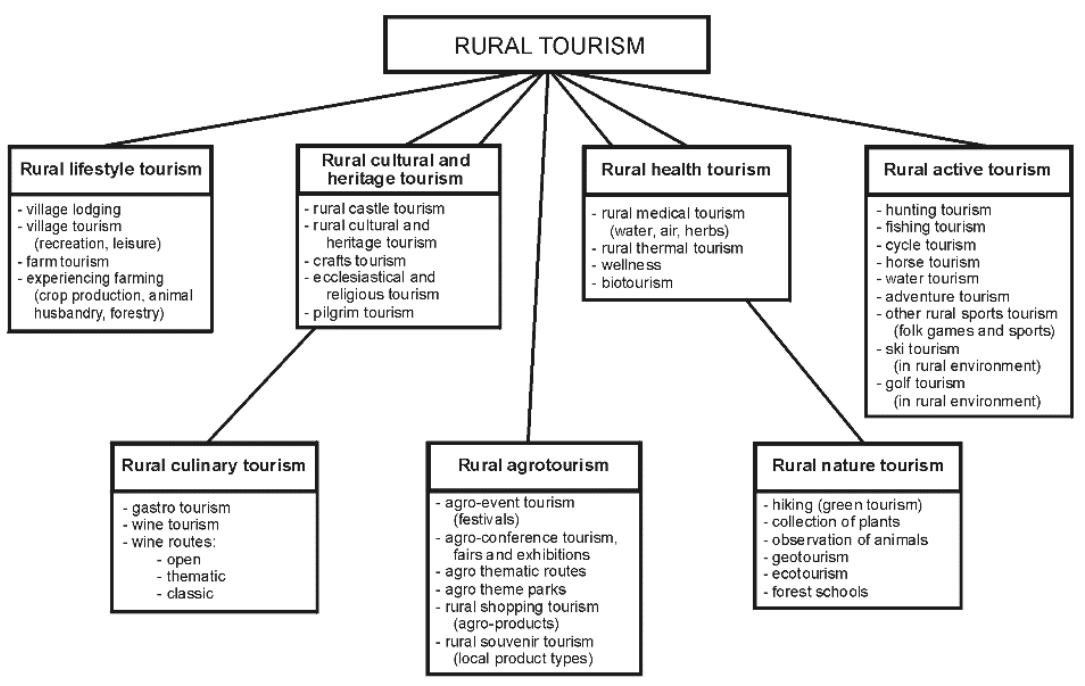

Source: David (ed. 2007)

The first one (David, 2007) is very useful for product management, and the second (Feher $\&$ Korodi, 2008) focuses on destination management. Their common advantage is that the experience management that has come to the fore since their extinction can play a decisive role in both cases. This is similar to Szabó's interpretation (2011), he also associates the concept of rural tourism with tourism products, but focuses more on the environmental experience. The results of the research also confirm this viewpoint with regard to environmental expectations.In summary it can be concluded that diversificated rural tourism offers show a special dichotomy. In spite of its variety it seems to be monotonous. This paradox statement includes the programs, attractions based on natural 
endowments, historic heritage, traditions of rural area, wide range of rural tourism services, which means its diversification. At the same time the offer is monotonous without features, each service provider proposes almost the same services. This can be justified by taking advantage of the multi-leg job option, however its effectiveness verified by the study is low.

Figure 5

Rural tourism as an intersection of different types of tourism

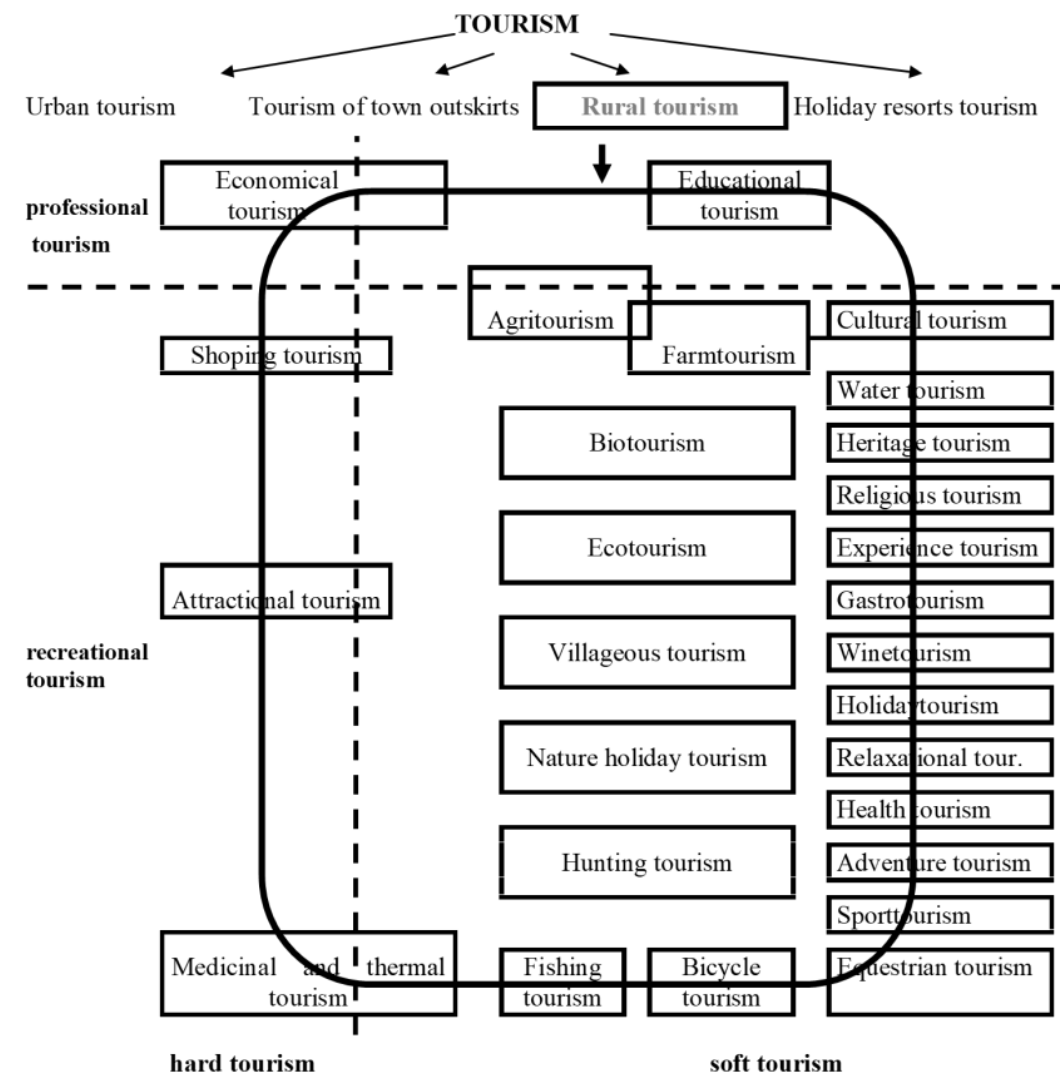

Source: Feher \&Korodi (2008)

In order to promote differentiation and the improvement of the position of rural tourism an increase of the ratio of offer elements is needed. It can be realised in several ways: in the function of endowments and the related offer, supported by marketing communication in different way and extent:

- providing general offer based on average endowments or

- absolute specific offer, which is based on outstanding endowments or

- unique offer, based on local endowments and conscious development of product or

- general offer based on conscious development.

Relationship of product components, supply and development, possible development variations are shown in a multi-dimension model (Figure 6).

Considering product components, a rural area can have outstanding endowment or just average one (for example: well-walked forest, fishing ponds, farm with animals, horses, 
craftsmen, etc.). From these ones a general offer - specific to rural sub-regions - can be created. For example: offering riding, animal caressing, touring, fishing opportunities. The other method is to create a specific offer, which means offering to visitors segmented by ages, interests, education or any other grouping method or offering attractions improved with experience elements.

The static model becomes dynamic with the third-dimension symbolizing development and progress. The rural tourism can extend by spontaneous development. It is determined by local people and businesses driven by their own interests, with their own endowments, but usually without a co-ordination attempt to utilize the opportunities given by tourism endowments. Conscious development means the preparation and implementation of the local tourism development concept. Development is indicated by a diagonal line. Getting in the desired spatial position (space 1) can be made step by step, always changing only one factor independently of their sequence (maximum 3 steps), or as result of complex development (common change of several factors). Some possible variations are indicated by arrows, or can be created as result of a high rate of development (for ex. 8. $\rightarrow 4$. $\rightarrow 2$. $\rightarrow 1$. position, or 6 . $\rightarrow$ 1.position).

Figure 6

Relationship of product components, supply and development - possible development variations

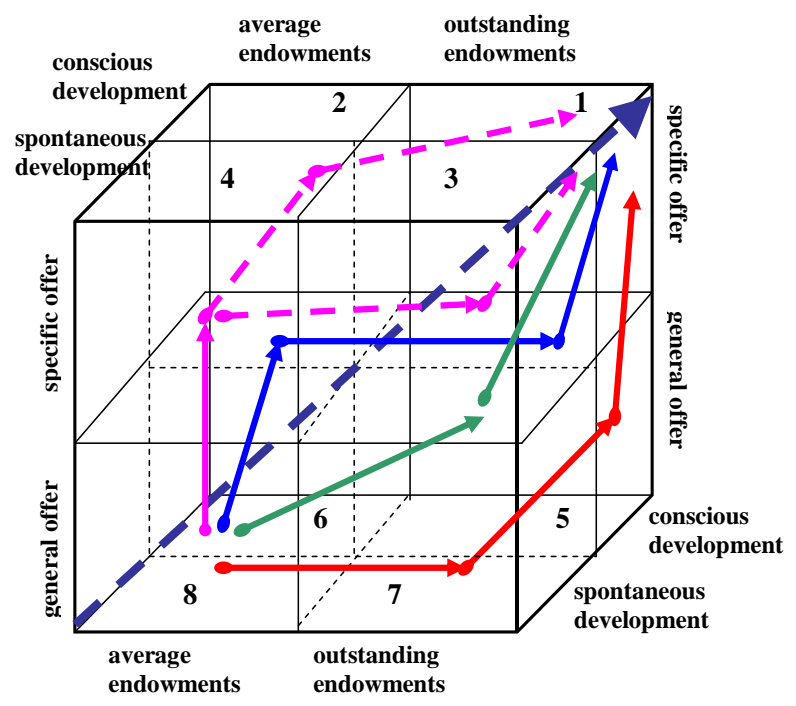

Source: Fehér \&Kóródi(2008)

One group of Hungarian rural areas is able to achieve a complex development, supporting sustainable economic increase, based on their tourism traditions and various attractions. This enables tourism to become a driving force and a central element of the development of the area. With development, the region can offer wide range and high-level tourism services, built into a uniform framework and efficient offerings. Therefore, the number and level of services should be increased to promote tourism development and also training, product development and marketing communication. The theoretic development model based on the endowments and offer can provide a forward look into the theory and practice of the rural tourism development. The results of this research also confirm the authenticity of the model. 
At the same time, it must be adopted and complemented by the view (Monaco, 2018) that market segments must be taken into account when designing the content of experiences, in particular the generational consumer habits.

The interpretation of special offer in the study of Mira et al (2018) is similar, supply development combines innovation and quality, which is attributed to conscious and unique product development. Uniqueness also requires the creativity of product developers and service providers, which is almost identical to Kiral'ova (2016). Extending the experience approach to previous researchers' resolutions, taking into account the feelings that can be experienced during travel becomes a factor that is closer to the travel decision.

\section{Conclusion}

Upon review of the relationship of rural development and tourism, it can be concluded that measures of rural development directly or indirectly support development of tourism, because these ones have significant influence on rural life conditions. The destination management process deals in complex way with the endowments of rural economy by putting these ones in service of tourism development of the rural areas. Tourism becomes a real integrating factor by application of destination management methods, because mobilisation of all the endowments of the entire region is necessary in order to increase attraction capability of the destination and its receiving capacity.

It would be advisable to define the basic, expected and extended level of services for rural tourism in the future. The optional points acquired represent the content of the service well, even though it is based on more technical equipment, but they do not help to enhance the rural character. While it is a positive development that service providers do not use inherited or previously replaced furniture, the spread of virtually accessible, modern refurbished, comfortable accommodation without rustic surroundings does not provide the result that would be the primary goal of rural tourism, namely allowing alternative income to local population, direct contact with guests, and insight into village life. The solution may be that rural service providers who do not offer such an experience are not included in databases, or another category would be established, that is rural accommodation without rural character. The abovementioned anomalies can mislead tourists, which also affects their satisfaction and appreciation of the given experience.

The local economies of the modern era are value-holders, value-creators and valuekeepers, they integrate into themselves the past, present and future. The local contexts preserved from the past played a determining role, which still have a significant impact on living conditions and employment. The present can be interpreted as the focus and importance of local development, and attributes a special role to the local economy. The future appears as a kind of alternative to the consumer society including local residents and tourists too.

The rural development - consequently related to the social, economic and environmental characteristics of the countryside- is based on mobilization of local endowments and their optimal utilization, and choosing such a ratio, which causes the highest speed of development (Rajnoha \& Lorincová, 2015). In a properly operating rural economics in 
any area of branches or activities there should be such an endowment mobilizing key factor, which is able to integrate the other factors to affect the other ones through its development in order to achieve development of using free endowments at high level. Tourism can also be this endowments' mobilizing (integrating) factor.

Internet-based data collection methods were only of limited use due to the size of the sample (Androniceanu, 2019), but it would be worthwhile to include in the regular municipal data collection supply-side parameters. Applying the new methods, based on the example of neighbouring countries (Simionescu, 2016), would also enrich the development strategy of settlements and regions with latent tourism potential.

It was manifest that the rural service providers located in less developed regions also have a few attractions. The reason of it is that one part of the programs created and organised as attraction, is expensive. A possible solution for them would be an attraction development based on a unique idea whose realization- with participation of residents would mean the promotion of such activities, meeting the requirements of local people, by providing jobs and income.

The results of the research and the applied simple observation method and developed rating scale may be suitable for analyzing and comparing rural tourism offerings in V4 countries, because they have similar characteristics in terms of rural tourism. The other direction of further research after analyzing the experience content of supply is to examine the demand, its experience promises and experience expectations by a quantitative survey. This would provide an opportunity to compare demand and supply experience characteristics.

\section{References}

1. Aho, S.K. (2001): Towards a General Theory of Touristic Experiences: Modeling Experience Process in Tourism. Tourism Review, 56, (3-4), 33-37. doi: 10.1108/eb058368

2. Androniceanu, Armenia (2019). The social sustainability of smart cities: urban technological innovation, big data management, and the cognitive internet of things, Geopolitics, History, and International Relations 11(1): 110-115. doi:10.22381/GHIR11120197

3. Boda, J. E. (2018): Examination of Adventure Park Consumers in Terms of Motivations and Amount of Leisure Time. Acta Oeconomica Universitatis Selye, 7 (2), 33-46.

4. Cole, S.T. \& Scott, D. (2004): Examining the Mediating Role of Experience Quality in a Model of Tourist Experience. Journal of Travel and Tourism Marketing, 16, (1), 77-78. ISSN 1054-8408

5. Dávid, L. (ed.), Jancsik, A. \& Rátz, T. (2007): Turisztikai erőforrások - A természeti és kulturális erőforrások turisztikai hasznositása, Budapest: Budapesti Gazdasági Főiskola

6. Fehér, I. \&Kóródi, M. (2008): A vidéki turizmus fejlesztése. Budapest: Szaktudás Kiadó Ház, . ISBN 978-963-9736-70-2

7. Gentile, Y. , Spiller, N. \& Noci, G. (2007): How to Sustain the Customer Experience: An Overview of Experience Components that Co-create Value with 
the Concumer. European Management Journal, 25, (5), 395-410. ISSN 02632373

8. Gonda, T. (2016): A turisztikai termékfejlesztés elméleti alapjai. Pécs: Pécsi Tudományegyetem KPVK, p.11.

9. Guilherme Nunes, F., Martins, L. M., Mozzicafreddo, J. (2018). The influence of service climate, identity strength, and contextual ambidexterity upon the performance of public organizations. Administratie si Management Public, (31), 6-20, DOI:10.24818/amp/2018.31-01

10. Kajzar, P. (2018): A Tourism Trends and Development of Selected Economic Indicators in the Moravian - Silesian Region Between 2006 - 2016. Acta Oeconomica Universitatis Selye 7 (1), 46-57.

11. Királ'ová, A.(2016): Creativity as a Tool of Tourism Development. In A. Királ'ová (Ed.) Driving Tourism through Creative Destinations and Activities pp. 67 doi: 10.4018/978-1-5225-2016-0.ch004

12. Korodi, M (2014): The Experience Expectations and Implementations of Participants in Tisza Riverside Tourism. In: Csata Andrea et al. (eds): Challenges in the Carpathian Basin: Global Challenges, Local Answers. Sapientia Hungarian University of Transylvania, Miercurea Ciuc, 530-539. ISBN 978-973-53-1287-9

13. Kovács, D. (2014): Élmény, élménygazdaság, élménytársadalom és turizmus. Turizmus Bulletin, 16, (3-4).40-48. ISSN 1587-0928

14. Kozicka, K., Kot, S., \& Riana, I. G. (2019). The Efficiency of Cooperation between the Participants in the Supply Chain in the Tourism-Related Branch of Industry in Relation to Client Satisfaction. Sustainability, 11(17), 4716.

15. Levytskyy, A (2015): Competitiveness of Tourism Product: Evaluation and Approaches to Provision. Journal of Geography, Politics and Society 2,7-18.

16. Mira, M., Moura, A. \& Mónico, L. (2018) A New Measure of the Quality of Tourism Product. Journal of Tourism and Services 9 (17) doi: https://doi.org/10.29036/jots.v9i17.54

17. Monaco, S. (2018): Tourism and the new generations: emerging trends and social implications in Italy, Journal of Tourism Futures, 4 (1), 7-15. https://doi.org/10.1108/JTF-12-2017-0053

18. Morrison, A.M. (2018): Marketing and Managing Tourism Destinations. London: Routledge, 716. ISBN: 978-1138897281

19. Mura, L. (2017): Current Situation in Family Businesses. Managerial Trends in the Development of Enterprises in Globalization Era, 178-185. ISBN 978-80552-1739-0

20. Mura, L.\&Kljucnikov, A. (2018): Small Businesses in Rural Tourism and Agrotourism: Study from Slovakia. Economics \& Sociology, 11, (3), 286-300. ISSN 2071-789X

21. Rajnoha, R., \& Lorincová, S. (2015): Strategic Management of Business Performance Based on Innovations and Information Support in Specific Conditions of Slovakia. Journal of Competitiveness, 7, (1), pp. 3-21. doi: 10.7441/joc.2015.01.01

22. Roberts, L. \& Hall, D. (2004) Consuming the Countryside: Marketing for "Rural Tourism". Journal of Vacation Marketing, 10, (3), 253-263. ISSN 13567667

23. Simionescu, M. (2016): Competitiveness and Economic Growth in Romanian Regions. Journal of Competitiveness, 8, (4), 46 - 60. doi: 10.7441/joc.2016.04.03

24. Slusarczyk, B., Smolag, K., \& Kot, S. (2016) The supply chain of a tourism product. Actual Problems of Economics, (5), 197-207. 
25. Stamboulis, Y. \& Skayannis, P. (2003): Innovation Strategies and Technology for Experience-based Tourism. Tourism Management, 24, (1), 35-43.

26. Szabó, G. (2011) Products and Product Specialisations in Rural Tourism. Pécs: University of Pécs. ISBN: 978-963-642-435-0

27. Walls, A.R. , Okumus, F. , Wang, Y. \& Kwun, D.J. (2011): An Epistemological View of Consumer Experiences. International Journal of Hospitality management, 30, (1), 10-21. ISSN 0278-4319

28. Walters, D. \&Lancaster, G. (2000:) Value and Information - Concepts and Issues for Management. Management Decision, 37, (8), 643-656. ISSN 0025-1747

29. Zátori, A. (2014): A turisztikai élményteremtés koncepciói a gyakorlatban. Turizmus Bulletin 16, (3-4), 49-58. ISSN: 1587-0928

30. Zatori, A. (2013): Tourism Experience Creation from a Business Perspective. $\mathrm{PhD}$. Thesis. Budapest: Corvinus University of Budapest, 165.p.

\section{Brief description of Author/Authors:}

\section{Kóródi, Márta PhD}

College professor, University of Debrecen, Faculty of Economics anf Business, Szolnok Campus, Institute of Rural Development, Tourism and Sports Management, Hungary. Web: https://econ.unideb.hu, E-mail: dr.korodi.marta@econ.unideb.hu. Graduated in Economist Tourism and Catering. She has PhD (Management and Business) in 2006. Research fields: tourism, experience management, tourist product development.

\section{Dávid, Lóránt Dénes,}

Ordinary member of the European Academy of Sciences and Arts (EASA), full-professor, Szent István University, Department of Tourism and Hospitality, Gödöllö, Hungary University of Debrecen, Faculty of Economics and Business, Department of Tourism and Hospitality Management, Hungary. Web: www.szie.hu, E-mail: dr.david.lorant@gmail.com. Graduated in History, Geography, European Studies and Tourism. He has PhD (Earth Sciences/Geography) in 2001, and habilitations in 3 disciplines (Management and Business Administration, Environmental Sciences, and Regional Sciences). Research fields: tourism, geography, regional studies, environmentalism. 